\title{
The Use of Discourse Markers in Written Discourse by the Students at Aviation Polytechnic of Surabaya
}

\author{
Lusiana Dewi Kusumayati
}

\author{
Politeknik Penerbangan Surabaya \\ (lusiana dewikusumayati@dephub.go.id)
}

Article History: Submitted July 25 ${ }^{\text {th }}, 2020$; Accepted August 24 ${ }^{\text {th }}, 2020$; Published August $30^{\text {th }}, 2020$

\begin{abstract}
This research aims at investigating the use of DMs in expository essays written by Indonesian EFL learners with different levels of English language proficiency. 10 students from the second semester of Civil Airport Engineering Program at Politeknik Penerbangan Surabaya (Aviation Polytechnic of Surabaya) were taken as the sample. They were divided into two groups, high and low competence of writing skill. To represent the targeted DMs, it relies on Fraser's taxonomy. The result of students' writing indicates that students with high and low competence of writing skill employed comparable rates of discourse markers in their essays. Those who have lower competence of writing skill were found using more limited sets of discourse markers than those who have higher competence of writing skill. The students having low competence of writing skill were also found using these DMs in narrow range of functions and in a more limited set of positions. Moreover, the discourse markers that are used by the students having low competence of writing skill were found more redundant from the point of view of syntactic categories. On the other hand, the DMs used by the high competence of writing skill were found more varieties. It could be concluded that the use of discourse markers is affected by the levels of writing competence of EFL learners.
\end{abstract}

Keywords: discourse markers, EFL learners, English language proficiency, written discourse.

\begin{abstract}
Abstrak. Penelitian ini bertujuan untuk menginvestigasi penggunaan discourse markers di dalam teks ekspositori yang disusun oleh para taruna yang memiliki perbedaan level penguasaan bahasa Inggris. 10 taruna dari semester kedua Program Studi Teknik Bangunan dan Landasan di Politeknik Penerbangan Surabaya diambil sebagai sampel. Para taruna tersebut dibagi menjadi dua kelompok, yaitu kelompok dengan kemampuan menulis yang tinggi dan kelompok dengan kemampuan menulis yang rendah. Untuk mewakili target discourse markers, penelitian ini,dilakukan berdasarkan Fraser's taxonomy. Hasil tulisan taruna menunjukkan bahwa taruna memiliki kemampuan menulis yang dapat dibandingkan dalam penggunaan discourse markers di dalam esai mereka. Mereka yang memiliki kemampuan menulis rendah menggunakan jenis discourse markers yang lebih terbatas dibandingkan dengan mereka yang memiliki kemampuan menulis yang lebih tinggi. Para taruna yang memiliki kemampuan menulis rendah juga menggunakan discourse markers dengan fungsi yang lebih sempit dan posisi yang yang terbatas. Lebih lanjut, discourse markers yang digunakan oleh taruna dengan penguasaan menulis rendah cenderung berlebihan dilihat dari aspek sintaksis. Sebaliknya, discourse markers yang digunakan oleh taruna yang memiliki kemampuan tinggi dalam menulis cenderung bervariasi. Dengan demikian dapat disimpulkan bahwa penggunaan discourse markers dipengaruhi oleh tingkat kemampuan menulis yang dimiliki oleh taruna yang mempelajari bahasa Inggris sebagai bahasa asing.
\end{abstract}

Kata Kunci: discourse markers, EFL learners, Penguasaan Bahasa Inggris, written discourse. 


\section{INTRODUCTION}

The study of Discourse Markers has expanded in the past ten years. Actually since 1970, discourse markers have been analyzed widely. The interest in studying DMs is growing each year because the researcher realizes that study in this area is important to be conducted. During everyday communication, speakers use discourse markers a lot. Discourse Markers have been studied under various labels, for example discourse connectives (Blakemore, 1987, 1992), discourse operators (Redeker, 1990, 1991), discourse particles (Schorup, 1985), discourse signaling devices (Polanyi and Scha, 1983), phatic connectives (Bazanella, 1990), pragmatic connectives (van Dijk, 1979; Stubbs, 1983), pragmatic expressions (Erman, 1992), pragmatic formatives (Fraser, 1987), pragmatic markers (Fraser, 1988, 1990; Schiffrin, 1987), pragmatic operators (Ariel, 1994), pragmatic particles (Ostman, 1995), semantic conjuncts (Quirk et al., 1985), sentence connectives (Halliday and Hasan, 1976). (As cited in Fraser, 1999).

Various definitions have been proposed to describe the nature and functions of discourse markers. Schiffrin (1987: 31) defines discourse markers as "sequentially dependent elements that bracket units of talk." Another definition is stated by Maschler (1994: 325) who defines discourse markers as "a subcategory of metalingual expressions: those used to mark boundaries of continuous discourse." Redeker (1991: 1168) defines it as a discourse operator as an expression which is equipped "with the primary function of bringing to the listener's attention a particular kind of linkage of the upcoming utterance with the immediately preceding discourse context." Fraser (1999) defines discourse markers as a class of lexical expressions drawn primarily from the syntactic classes of conjunctions, adverbs, and prepositional phrases.

Discourse Markers study within the past ten years has been focusing in the theoretical status of DMs, focusing on what DMs are, what DMs mean, and what function(s) they deliver. Discourse markers are worth to be studied because in a piece of writing, without discourse markers, a text would not seem logically constructed and the connection between the different sentences and paragraphs would not be obvious. This study also conducted considering the fact that in Indonesian context, many students tend to over-use some discourse markers. Too many discourse markers can make a piece of writing become too heavy and not genuine. Study in this area should be conducted to notice those weaknesses then later teach our students that discourse markers are important, but they must be only used when necessary. It is common to analyze Discourse Markers of spoken discourse, but I will focus here on the use of discourse markers in written discourse in Indonesian students' context.

This study analyzes the use of DMs in expository essays written by the Indonesian students with different levels of English language proficiency. It attempts to discuss the effect of English language proficiency on the use of DMs. The study will attempt to answer this question: How does the level of proficiency of students at the second semester of Civil Airport Engineering Program in Politeknik Penerbangan Surabaya (Aviation Polytechnic of Surabaya) affect their use of DMs in written discourse?

Fraser (1999) characterizes a DM as a linguistic expression only which: (i) has a core meaning, which can be enriched by the context; and (ii) signals the relationship that the speaker intends between the utterance the DM introduces and the foregoing utterance. He uses constructed examples for analyzing DMs within a grammatical-pragmatic framework. 
A discourse marker is defined by Fraser (1999: 951) as a pragmatic class, lexical expressions drawn from the syntactic classes of conjunctions, adverbials, and prepositional phrases.

Fraser (1999) adds certain characteristics that DMs signal a relationship between the segment they introduce, S2, and the prior segment, S1. They have a core meaning which is procedural, not conceptual, and their more specific interpretation is 'negotiated' by the context, both linguistic and conceptual. Meanwhile, Hiilker (1991: 78-79) gives attention that there are four basic features that characterize discourse markers: (1) they do not affect the truth conditions of an utterance; (2) they do not add anything to the propositional content of an utterance; (3) they are related to the speech situation and not to the situation talked about; and (4) they have an emotive, expressive function rather than a referential, denotative, or cognitive function.

Fraser (2009) identifies three functional classes of DMs: 1) contrastive discourse markers (CDMs) which signal that the message conveyed by the discourse segments they introduce contrasts directly or indirectly with the prior segments; 2) elaborative discourse markers (EDMs) which indicate that the information contained in the discourse segments that host them is an elaboration on the information represented by prior segments; 3) inferential discourse markers (IDMs) where the discourse segment they introduce "provides a basis for inferring" the prior segment (Fraser, 2009: 9).

Ali \& Mahadin (2016) relies on Fraser taxonomy and adopts functional approach to investigate the use of DMs in expository essays written by Jordanian EFL learners with different levels of English language proficiency. The result of their study concludes that the use of DMs is affected by EFL learners' proficiency levels. "Lower proficiency EFL learners tend to use more restricted and redundant sets of DMs. Lower levels of proficiency might result in restricting the functions that are served by DMs, limiting the syntactic categories from which these markers are drawn and affecting the variety of the positions that they occupy" (Ali \& Mahadin, 2016: 32).

Martinez (2004) investigates the use of DMs in written discourse by non-native speakers of English. She uses Fraser's taxonomy to carry out his study. The subjects of her research are 78 Spanish university students who are asked to write expository compositions. The researcher concludes that Spanish students use a variety of DMs with different degrees of frequency. She points out that the discourse markers which are exhibiting the highest degree of frequency in the students' writings are the elaborative markers. The result of her study also finds that there is a positive relationship between the qualities of the students' compositions and the variety of the DMs used by them. The highly-rated compositions generally "tended to present a larger variety" of elaborative, inferential and contrastive markers. The poorly- rated compositions, on the other hand, tended to present a redundant use of the contrastive markers 'but' and 'however'.

Jalilfar (2008) contributes her choice of Fraser's taxonomy to the fact that "it conforms to written discourse and it seems to be the most comprehensive classification in written discourse" (Jalilfar, 2008, p.115). 90 Iranian university students were asked to write descriptive compositions once a week for 8 weeks. She also emphasizes that there is a significant relationship between the frequency of DMs and the quality of the compositions. Based on her study, elaborative markers are most frequently used class of DMs.

Zarei (2013) conducted study to examine what discourse markers (DM) and their characteristics are in English. It described the range of uses of English discourse markers in 
conversations included in Interchange books. It also determined that "oh" and "well" were the most frequently used discourse markers in the conversations, and then the functions of them were explored to find the reason why the spoken discourse of the speakers was replete with forms such as "oh" and "well". The study implies that there is a need to make learners aware of these markers and their pragmatic functions. Teachers' use of discourse markers as a model for students is also really crucial in teaching language in classroom settings.

Adewibowo, D., Imranuddin, \& Azwand (2018) found the types of Discourse Markers used by the students and investigating the accuracy of Discourse Markers by the students of English Education Study program graduated in December 2016 at the University of Bengkulu. This descriptive study used 10 theses background from the students of English Education Study Program who graduated in December 2016. The result of this research shows that there were four types of Discourse Markers used by the students based on Bruce Fraser's theory such as Inferential markers, temporal markers, elaborative markers and contrastive markers. The most dominant marker used by the students was Inferential markers with $42 \%$. This research also found that the most accurate marker used was Temporal markers with $78.57 \%$ and the lowest accurate marker was Elaborative markers with $52.17 \%$.

Mumbi \& Simwinga (2018) examined challenges experienced in the use of DMs in composition writing by a sample of 150 Grade Twelve (G12) ESL learners selected from three secondary schools in Kitwe district, Zambia. The data were collected from 300 scripts comprising two samples of written pieces of discourse produced by each of the 150 pupils. The researcher employed descriptive research design with text analysis as specific research approach based on the perspective of written discourse as rule-structured object or product of a completed activity. A four-stage qualitative approach was applied in data analysis, guided by Fraser's (1999) taxonomy of discourse markers, involving marking and scoring out of 20 each of the 300 scripts, locating the DMs used in each of the 300 scripts, classifying each of the DMS according to its communicative function as either propositional or nonpropositional and, finally, identification and cataloguing of instances of inappropriate uses of DMs as reflection of the challenges experienced. The findings indicate that participants experience a multiplicity of challenges in the use of DMs.

Al-khazraji (2019) threw more light in measuring the students' knowledge about Discourse Markers. This paper aims to exponentiate the Discourse Markers in ESL students' essay writing. The Qualitative data was collected from intermediate students of grade 9 from a school in Dubai. Six of their essays were chosen randomly and only nine extracts were analyzed. These extracts focus on how students use Discourse markers with cohesion and coherence. The findings were categorized into three parts: Misused Discourse Markers', Overused Discourse Markers', and Advanced used Discourse Markers'.

\section{METHOD}

\section{Subjects}

The subjects of the study are divided into two groups. The first group is high competence of EFL learners they are represented by five diploma students in the Civil Airport Engineering Program at the Aviation Polytechnic of Surabaya. The divisions of the study are determined based on the result of pre-test conducted by the research before collecting data. The subjects who are classified as high competence of EFL learners obtained pre-test score of 80 or more. The other group of subjects is low competence of EFL learners and they are represented by 
5 students who obtained pre-test score under 70. Ten subjects are randomly selected from the 30 students. The sample of the advanced EFL learners presents around 33\% of the population from which it is drawn. From 30 students, 5 of them considered as having high competence, and 5 of them considered as having low competence. 20 others are considered in between or in the medium level of competence. Since the sample here taken into high and low, so 10 students who are divided into two groups (high and low) were used as the sample.

\section{Data collection}

This study used writing essays as the instrument for collecting the data. The subjects were asked to write expository essays in which they discuss for two topics given by the lecturer. The selection of this topic is based on the assumption that it is familiar to the subjects. The subjects are asked to write the essays during regular classroom sessions.

\section{Model of analysis}

This study used Fraser's (2009) taxonomy to represent the targeted Discourse Markers. Fraser's taxonomy was used considering that in written discourse; Fraser's taxonomy has the most comprehensive classification. The analysis of Discourse Markers in this study was based on three functional classes of discourse markers produced by Fraser (2009). It was also used temporal class of DMs which was considered by Fraser (2005) as a subclass of DMs. The following are the division class of DMs which will be used in this research:

\section{Contrastive discourse markers (CDMs)}

Fraser (2009: 8) states that this classification of DMs includes but, alternatively, although, contrariwise, contrary to expectations, conversely, despite (this/that), even so, however, in spite of (this/that), in comparison (with this/that), in contrast (to this/that), instead (of this/that), nevertheless, nonetheless, (this/that point), notwithstanding, on the other hand, on the contrary, rather (than this/that), regardless (of this/that), still, though, whereas, yet.

\section{Elaborative discourse markers (EDMs)}

Fraser (2009: 9) states that this classification of DMs includes and, above all, after all, also, alternatively, analogously, besides, by the same token, correspondingly, equally, for example, for instance, further (more), in addition, in other words, in particular, likewise, more accurately, more importantly, more precisely, more to the point, moreover, on that basis, on top of it all, or, otherwise, rather, similarly, that is to say.

\section{Inferential discourse markers (IDMs)}

Fraser (2009: 9) states that this classification of DMs includes so, all things considered, as a conclusion, as a consequence ( of this/that ), as a result ( of this/that ), because (of this/that ), consequently, for this/ that reason, hence, it follows that, accordingly, in this/that/any case, on this/that condition, on these/those grounds, then, therefore, thus).

\section{Temporal discourse markers (TDMs)}

Fraser (2005: 197) states that this classification of DMs includes then, after, as soon as, before, eventually, finally, first, immediately afterwards, meantime, meanwhile, originally, second, subsequently, when. 


\section{Data analysis}

The subjects' use of DMs is judged based on four criteria: 1) the frequency of the use of DMs; 2) the functions that DMs serve in expository essays; 3) the variety of the use of DMs; 4) the syntactic categories from which DMs are drawn; and 5) the position that DMs occupies in sentences and in discourse segments.

\section{RESULTS AND DISCUSSION}

\section{Frequency of occurrence}

The high and low competence of EFL learners used a total of 292 DMs. The low competence of learners employed $124 \mathrm{DMs}$ in their expository writing and the high competence learners employed 168 DMs. Every 18 words, both groups of learners used DMs. The difference in the frequency between the high and the low competence of EFL learners was not really far. The number of DMs used by the high competence learners accounted for $57.5 \%$ of the identified instances. As for the high competence of EFL learners, the percentage of frequency accounted for $42.5 \%$. The frequency of DM occurrences can be in the following table:

Table 1 The frequency of DM occurrences in expository writing

\begin{tabular}{c|c}
\hline Level & Percent \\
\hline Advanced & $57.5 \%$ \\
\hline Intermediate & $42.5 \%$ \\
\hline
\end{tabular}

\section{Functions}

The functions that these DMs serve in expository essays are the second criterion used to analyze the students' use of DMs. The frequencies of the functional classes of the DMs are presented in Table 2.

Table 2 The frequency of the functional classes of DMs

\begin{tabular}{l|c|c|c}
\hline \multirow{2}{*}{} & High & Low & Total \\
\cline { 2 - 4 } & Percent & Percent & Percent \\
\hline Elaborative & 58.9 & 65.3 & 61.6 \\
\hline Contrastive & 11.3 & 7.3 & 9.6 \\
\hline Inferential & 16.7 & 15.3 & 16.1 \\
\hline Temporal & 13.1 & 12.1 & 12.7 \\
\hline
\end{tabular}

It can be seen from Table. 2 that elaborative markers were the most frequently employed (61.6\%), followed by inferential markers (16.1\%), temporal markers (12.7\%), and contrastive markers $(9.6 \%)$. The extensive use of elaborative markers by the advanced and intermediate EFL learners might be contributed to the fact that expository writing typically requires elaboration of ideas which might be signaled by the use of the elaborative category of DMs (Martinez, 2004; Jalilifar, 2008; Asassfeh, et al., 2013; Ali \& Mahadin, 2016). It should be also paid attention that the low competence of EFL learners $(65.3 \%)$ used elaborative markers more frequently than the high competence ones (58.9\%). Jalilifar (2008: 116), who reported a similar result, observes that there is "a negative relationship between increase of composition writing ability and the use of elaborative DMs." the rate of DMs other than elaborative markers increased, but elaborative markers decreased" (Jalilifar, 2008: 
116). This assumption might be verified by the fact that the temporal, inferential and contrastive markers were used more frequently by the advanced EFL learners (Ali \& Mahadin, 2016: 29). The result also shows that contrastive class of DMs was rarely used by the students, especially for the low competence of EFL learners.

\section{Variety of use}

To identify whether the students used varied or restricted sets of DMs, the DMs are categorized under the four functional classes. The following explanation presents a qualitative analysis of the variety of use of the DMs that are grouped under elaborative, contrastive, inferential, and temporal of DMs.

\section{The variety of elaborative markers}

Elaborative markers were the most frequently used by the high and low competence of writing skill EFL learners. The variety of elaborative markers is presented in the following table:

Table 3 The frequency of the elaborative markers

\begin{tabular}{l|c|c}
\hline \multirow{2}{*}{} & High & Low \\
\cline { 2 - 3 } & Percent & Percent \\
\hline and & 60.5 & 83.1 \\
\hline also & 15.4 & 6.2 \\
\hline for example & 10.1 & 1.3 \\
\hline furthermore & 1.9 & 0.0 \\
\hline in addition & 1.1 & 0.0 \\
\hline in other words & 1.1 & 0.0 \\
\hline moreover & 5.3 & 1.9 \\
\hline or & 2.3 & 5.6 \\
\hline besides & 2.3 & 1.9 \\
\hline
\end{tabular}

The results show that the high and low competence of EFL learners overused the DM 'and'. It showed that the low competence overuse the DM 'and' in comparison to the high competence. Accordingly, this maker constituted a ratio of $83.1 \%$ of the entire set of the elaborative markers that were used in the low competence of EFL learners' essays as opposed to $60.5 \%$ employed in essays written by the high competence learners. Example below is the redundant use of 'and' by the low competence of EFL learners.

Suitable foundation soil is required for its stability. And its properties need to be checked. (low competence)

Beside 'and', the DM that was used more frequently by the low competence of EFL learners was 'also'. The DMs (for example, moreover, and besides) were used more frequently by the high competence learners. Furthermore, the low competence of EFL learners did not use some category of DMs (furthermore, in addition, and in other words).

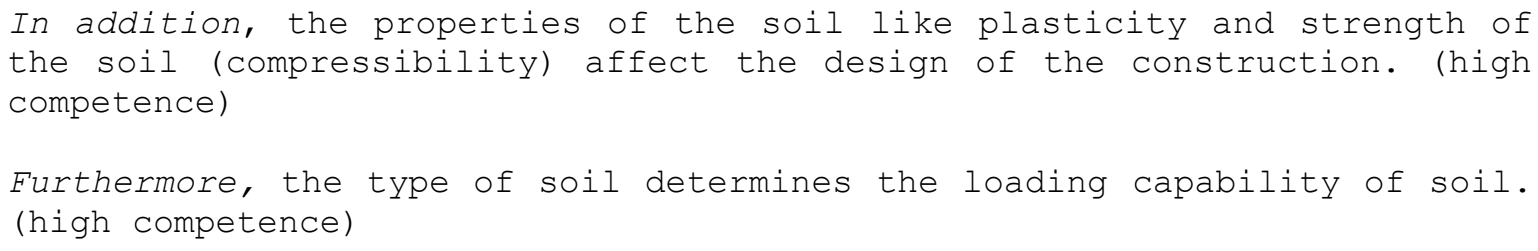


From the above findings, it can be seen than high competence of EFL learners used more variations than the low competence of EFL learners. It is similar with Ali \& Mahadin (2016) who say that "the intermediate learners used relatively a more restricted set of elaborative DMs in their essays and relied heavily on the DM 'and' to compensate for their unfamiliarity with the other elaborative markers".

\section{The variety of contrastive markers}

Contrastive markers were the least frequently employed category of DMs according to the findings. The findings found that the DM ' $b u t$ ' accounted for a ratio of $87 \%$ of the entire set of contrastive markers used by the low competence of EFL learners.

Table 4 The frequency of the contrastive markers

\begin{tabular}{l|c|c}
\hline \multirow{2}{*}{} & High & Low \\
\cline { 2 - 3 } & Percent & Percent \\
\hline although & 0.00 & 3.0 \\
\hline but & 31.4 & 89.0 \\
\hline even though & 2.5 & 0.0 \\
\hline however & 22.0 & 0.0 \\
\hline on the other hand & 27.0 & 4.0 \\
\hline still & 2.5 & 0.0 \\
\hline while & 14.6 & 4.0 \\
\hline
\end{tabular}

The contrastive markers (but and while) considered as contrastive DMs used by the low competence of EFL learners. Example below illustrates the use of contrastive markers by the low competence of EFL learners.

Airlines routes to rural airports would be beneficial, but they wouldn't do that because they are not profitable. (low competence)

The high competence of EFL learners, on the other hand, used a more variations of contrastive DMs in their essays. The contrastive DMs (but, however and on the other hand) were the mostly frequently used in the high competence of EFL learners' data. Other types of contrastive markers in the high competence of EFL learners' essays include (although, even though, still, and while).

Improving funding to rural airports will help the economies of rural areas while large airports will get support to handle the increase in traffic. (high competence)

\section{The variety of inferential markers}

The inferential makers had a slightly lower frequency in the low competence of EFL learners; a deeper analysis indicates that the low competence of EFL learners used a restricted set of this category in comparison with the high competence of EFL learners. The analysis of the occurrences of the inferential markers in the learners' essays is presented in the following table.

Table 5 The frequency of the inferential markers

\begin{tabular}{l|c|c}
\hline \multirow{2}{*}{} & High & Low \\
\cline { 2 - 3 } & Percent & Percent \\
\hline because & 31.30 & 55.0 \\
\hline
\end{tabular}




\begin{tabular}{l|c|c}
\hline because of & 9.30 & 2.9 \\
\hline consequently & 4.90 & 0.0 \\
\hline in this case & 2.40 & 0.0 \\
\hline so & 24.80 & 32.0 \\
\hline so that & 14.60 & 1.4 \\
\hline then & 3.40 & 6.4 \\
\hline therefore & 9.30 & 2.3 \\
\hline
\end{tabular}

Both the high and low competence of EFL learners relied heavily on the DMs 'because' and ' $s o$ ' to signal a relationship of inference between discourse segments. From the findings, it can also be seen that the high competence of EFL learners used a varied set of inferential markers in contrast to the low competence of EFL learners who neglected the use of other markers that are grouped under the inferential category of DMs. The inferential markers (consequently, in this case, then, and therefore) occurred in the high competence of EFL learners' essays. The type of inferential markers used by the low competence of EFL learners only included 'so', 'because', 'so that', 'then', 'therefore' and 'because of'. The example below represents the use of inferential markers by the high competence of EFL learners.

Both small and large airports managers could come together to make agreement because they could discuss to offer sufficient flights for people to fly. (high competence)

In this case, both large and small airports could be ready and get benefit through correct planning. (high competence)

So, removing the air service is going to have significant impact on the economy. (high competence)

\section{The variety of temporal markers}

Ali \& Mahadin (2016: 28) state that temporal DMs serve the function of signaling structural relations between the segments that host them and prior discourse segments. The frequency of the temporal DMs in the learners' expository writing is presented in the following table.

Table 6 The frequency of the temporal markers

\begin{tabular}{c|c|c}
\hline & High & Low \\
\cline { 2 - 3 } & Percent & Percent \\
\hline After & 18.30 & 0.0 \\
\hline Then & 35.30 & 85.0 \\
\hline Before & 12.4 & 0.0 \\
\hline When & 34.0 & 15.0 \\
\hline
\end{tabular}

Table 6 indicates that not so many varieties of temporal DMs were used by the high and the low competence of EFL learners. However, it is observed that the high competence of EFL learners used a more varied set of temporal markers which is different from the set used by the other group. The high competence of EFL learners used frequently the temporal markers 'after' and 'before' which are not occurred in the low competence learners' data. The following examples illustrate the use of temporal markers in the high and low competence learners.

After proper design and construction of civil engineering structures have been analyzed, then it is essential to have detail exploration. (high competence) 
When the foundations are constructed on compressible soil, it will be safe to build construction. (low competence)

\section{Syntactic categories}

The DMs that are analyzed in the present study are drawn from five syntactic categories, namely, coordinate conjunctions, subordinate conjunctions, prepositions, prepositional phrases, and adverbials. The following table can explain the use of each category:

Table 7 The frequency of the syntactic categories of DMs

\begin{tabular}{l|c|c|c}
\hline & High & Low & Total \\
\cline { 2 - 4 } & Percent & Percent & Percent \\
\hline Coordinate conjunctions & 31.1 & 52.10 & 41.6 \\
\hline Subordinate conjunctions & 18.2 & 18.1 & 18.2 \\
\hline Adverbials & 30.2 & 17.0 & 23.6 \\
\hline Prepositions & 3.1 & 0.00 & 1.6 \\
\hline Prepositional phrases & 17.6 & 11.50 & 14.6 \\
\hline
\end{tabular}

As shown in Table 7 , the syntactic category of coordinate conjunctions (41.6\%) was the most frequent source of DMs in the present study, followed by adverbials $(23.6 \%)$, subordinate conjunctions (18.2\%), prepositional phrases (14.76\%), then prepositions (1.6\%). Students who have low competence in writing skill used the coordinate conjunctions (but, and, or) at higher percentage in their data. The use of coordinate conjunction is dominant since the gap of percentage use of this category is far compared to other categories. Both of high and low competence overuses the elaborative marker 'and' and contrastive 'but'. It can be seen from the result of their use of coordinate conjunction, $31.1 \%$ for those who have high competence and $52.1 \%$ for those who have low competence. It can be assumed that low competence students extreme over-reliance on the elaborative marker 'and' and the contrastive marker 'but'.

Comparable percentages can be found on the use of subordinate conjunction. The high competence students used $18.2 \%$ while the low ones use $18.1 \%$. When it is critically take a look into their writing, the high competence used more variations of subordinate conjunction (for example although, even though, while). The low competence students tend to use 'so' and 'because' over and over again. The adverbial category of DMs was used more frequently by the advanced learners. They more varieties markers that belong to the adverbial category than what had been used by low competence learners. They used still, therefore, moreover, and however. The same findings also occurred for the syntactic categories of prepositions and prepositional phrases. Those who have high competence used more frequently a varied set of DMs that belong to these categories: for example, in addition, and in other words.

\section{Sentence position}

In a sentence, DMs may appear initially, medially or finally. Based on the findings of this study, the positions of DMs use in the learners' data were initially or medially. The positions that DMs occupied in essays written by the low and high competence EFL learners are presented in the following table. 
Table 8 The frequency of the sentence positions of DMs

\begin{tabular}{c|c|c}
\hline & High & Low \\
\cline { 2 - 3 } & Percent & Percent \\
\hline Initial & 38.3 & 20.4 \\
\hline Medial & 61.7 & 79.6 \\
\hline
\end{tabular}

The findings found that the low competence learners (79.6\%) employed DMs in sentencemedial position more frequently than the high competence learners $(61.7 \%)$. It might be happened because the low competence learners overused the DMs from coordinate conjunctions category (and, but, or). Coordinate conjunction as we know the grammar rule, tend to appear sentence-medially. The high competence learners used the other types of syntactic categories like adverbials or prepositional phrases as sources of DMs more frequently than the low competence learners. The DMs from adverbials or prepositional phrases categories tend to appear in the initial position.

Besides, the low competence learners tend to use DMs in sentence-medial position more frequently than the high competence learners might because the low competence ones had a higher percentage of elaborative markers than the high competence learners. Sentence-initial position which was used frequently by the high competence learners might because they tend to use temporal markers. This type of marker had a higher ratio of use in sentence-initial position.

\section{CONCLUSION}

The findings of this study found that the use of Discourse Markers in expository essay written by Aviation Polytechnic of Surabaya Students is affected by their proficiency levels. Higher proficiency EFL learners tend to use more varied sets of DMs. Lower levels of proficiency used restricted and redundant sets of DMs. they restrict the functions that are served by DMs, limit the syntactic categories and affect the positions in the sentence. This research still needs to be developed in case of the subject involved, the duration, and the text type. The next researcher can widen the scope of the research subject. Besides, the time of the research and also the type of the text used in the research should also be considered in order to give more data in the future.

\section{REFERENCES}

Adewibowo, D., Imranuddin, \& Azwand. (2018). A Study of Discourse Markers Used in the Theses Background Written by the Students of english department of bengkulu University (Academic Year December 2016). Journal of English Education and Teaching (JEET) Vol.2.No.3.2018

Al-khazraji, A. (2019). Analysis of Discourse Markers in Essays Writing in ESL Classroom. International Journal of Instruction April 2019 Vol.12, No.2 e-ISSN: 1308-1470

Ali, E.A. Mahmoud \& Mahadin, R. Salim. (2016). The Use of Discourse Markers in Written Discourse by Students of English at the University of Jordan. International Journal of Humanities and Social Science. Center for Promoting Ideas, USA

Fraser, B. (1999). What are discourse markers? Journal of Pragmatics, 31, 931-952. 
Fraser, B. (2005). Towards a theory of discourse markers. In: Fischer, Kerstin (Ed.), Approaches to discourse particles, (pp.189-204). Amsterdam: Elsevier Press.

Fraser, B. (2009). An account of discourse markers. International Review of Pragmatics, $1,1-28$.

Hiilker, Klaus, (1991). Franziisisch: Partikelforschung. Lexikon der Romanistischen Linguistik, vol. V. 1, 77-88.Tiibingen: Niemeyer.

Jalilfar, A. (2008). Discourse markers in composition writings: The case of Iranian learner of English as a foreign language. English Language Teaching, 1(2), 114-122.

Martinez, A. (2004). Discourse markers in the expository writing of Spanish university students . IBÉRICA, 8, 63-80.

Maschler, Y. (1994). Mitigating and discourse markers in bilingual conversation. Language in Society, 23, 325-366.

Mumbi, C.M. \& Simwinga, J. (2018). Challenges in the Use of Discourse Markers in English as Second Language (ESL) Writing: Evidence from Selected Grade Twelve Pupils in Kitwe District, Zambia. International Journal of Humanities and Cultural Studies, Vol 5 (2)

Redeker, G. (1991). Linguistic markers of discourse structure. Linguistics, 29, 1139-1172.

Schiffrin, D. (1987). Discourse Markers. Cambridge: CUP.

Zarei, Fatemeh. (2013). Discourse Markers in English. International Research Journal of Applied and Basic Sciences Vol, 4 (1): 107-117. Science Explorer Publications 